\title{
Methodology for post-event analysis of flash floods - Svacenický Creek case study
}

\author{
Lotta BLAŠKOVIČOVÁ ${ }^{1}$, Oliver HORVÁT ${ }^{2}$, Kamila HLAVČOVÁ ${ }^{2}$, \\ Silvia KOHNOVÁ2 ${ }^{2}$, Ján SZOLGAY² \\ ${ }^{1}$ Slovak Hydrometeorological Institute \\ Jeséniova 17, 83315 Bratislava, Slovak Republic; \\ e-mail: lotta.blaskovicova@shmu.sk \\ ${ }^{2}$ Faculty of Civil Engineering, Slovak University of Technology \\ Radlinského 11, 81368 Bratislava, Slovak Republic; \\ e-mail: oliver.horvat@stuba.sk, kamila.hlavcova@stuba.sk, silvia.kohnova@stuba.sk, \\ jan.szolgay@stuba.sk
}

\begin{abstract}
In this paper a methodology for a post-event analysis of a flash flood and estimation of the flood peak and volume are developed and tested. The selected flash flood occurred on the $6^{\text {th }}$ of June, 2009 in the Svacenický Creek Basin. To understand rainfallrunoff processes during this extreme flash flood, the runoff response was simulated using the spatially-distributed hydrological model KLEM (Kinematic Local Excess Model). The distributed hydrological model is based on the availability of raster information about the landscape's topography, soil and vegetation properties and radar rainfall data. In the model, the SCS-Curve Number procedure is applied to a grid for the spatially-distributed representation of the runoff-generating processes. A description of the drainage system's response is used to represent the runoff's routing. The simulated values achieved by the KLEM model were comparable with the maximum peak estimated on the basis of the post-event surveying. The consistency of the estimated and simulated values from the KLEM model was evident both in time and space, and the methodology has shown its practical applicability.
\end{abstract}

Key words: flash flood, Svacenický Creek, post-event analysis, KLEM - distributed hydrological model

\section{Introduction}

Flash floods are processes that occur in basins of a few hundred square kilometers or less and with response times of a few hours or less (Borga et al., 
2007). In recent years many extreme flash floods have been discussed in the literature (e.g., Norbiato et al., 2003; Gaume et al., 2004; Anquetin et al., 2005; Delrieu et al., 2005; Borga et al., 2007; Gaume et al., 2009), and methodologies for improving the estimation and forecasting of flash floods have been proposed. An important problem in estimating the behaviour, peaks and volumes of flash floods is the lack of measured data, particularly in small ungauged catchments. Approaches based on estimating threshold characteristics, such as threshold runoff or rainfall, indicate maximal sustainable surface runoff for a given basin. A methodology for estimating a threshold runoff in an operational flash flood warning system using GIS was developed by Carpenter et al. (1999). In Norbiato et al. (2008), a threshold-based flash flood warning method was developed and tested for different climatic and physiographic conditions. This flash flood guidance methodology follows from an estimation of the threshold depth of a uniform rainfall with a given duration, which can cause flooding at the outlet of a basin. Georgakakos (2006) developed an analytical solution for operational flash flood guidance systems based on the relationships between the rainfall volume of a given duration and the resulting volume of the surface runoff.

Hydrological distributed models with a high spatial resolution of physiographical and morphological basin characteristics have been used to limit uncertainties in estimating flash floods. For the operational forecasting of flash floods in northern Austria, Bloeschl et al. (2008) developed a spatially distributed model with a grid-based structure for runoff generation and a lumped structure for flood routing in river reaches. Younis et al. (2008) examined short-range numerical weather forecasts with a spatially distributed rainfall-runoff model for early flash flood warnings in ungauged river basins. The methodology is based on flood thresholds continually simulated using the LISFLOOD hydrological model. Reed et al. (2007) proposed a methodology for improving the accuracy of flash flood forecasts at ungauged sites based on distributed hydrologic modelling and a threshold frequency. During rainfall events, the model simulates the grids of peak flow forecast frequencies with a high resolution; these grids are then compared to locally-derived threshold frequency grids.

This paper concentrates on a flash flood which occurred in the basin of Svacenický Creek in 2009 and caused a great amount of property damage. In the paper a description of the basin along with the selected flash floods is 
set out, and the results of the post-survey reconstruction of the flash flood event are described. The next section contains the description of the KLEM model, the processing of the data required and the results of simulating the selected flash flood by the KLEM model. In the last part of the paper the results achieved are summarized and discussed.

\section{Description of the Svacenický Creek Basin}

Svacenický Creek, which is located in the western part of Slovakia, is the right tributary of the Myjava River. Its confluence with the Myjava River is in the Myjava - Turá Lúka town (Fig. 1).
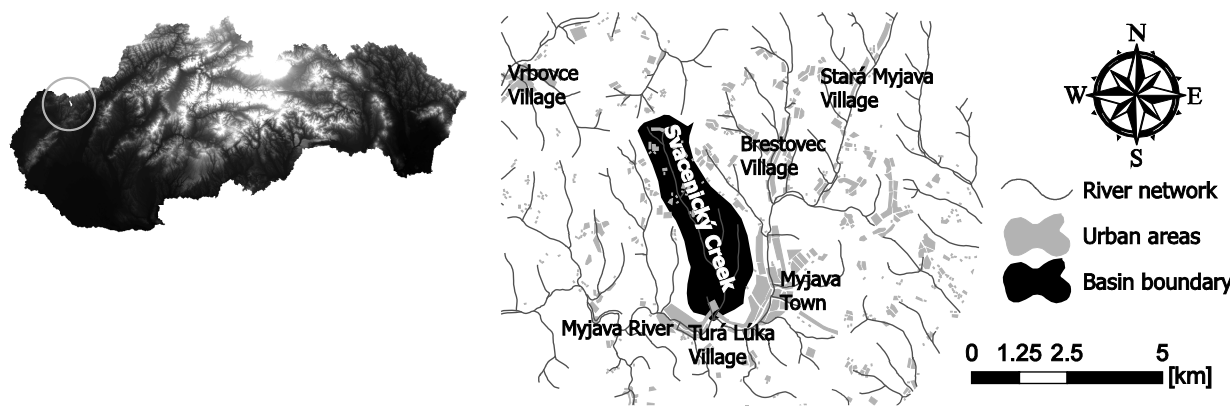

Fig. 1. Location of the Svacenický Creek Basin.

The Svacenický Creek Basin has an elongated shape with a mean width of 1 to $1.5 \mathrm{~km}$ and with a $5.7 \mathrm{~km}$ long valley. The highest elevation of the catchment is $544 \mathrm{~m}$ a.s.l.; the outlet is at $310 \mathrm{~m}$ a.s.l. The mean gradient of the slopes in the basin reaches $5.85^{\circ}$ (Fig. 2).

There are several small unnamed tributaries to the left of the Svacenický Creek Basin and there is only one small tributary near a gauging station on the right side. The gauging station is located at a $100 \mathrm{~m}$ distance from the confluence of the Myjava River. The whole area of the Svacenický Creek Basin covers $6.86 \mathrm{~km}^{2}$, to the gauging station $6.85 \mathrm{~km}^{2}$ (Table 1). 


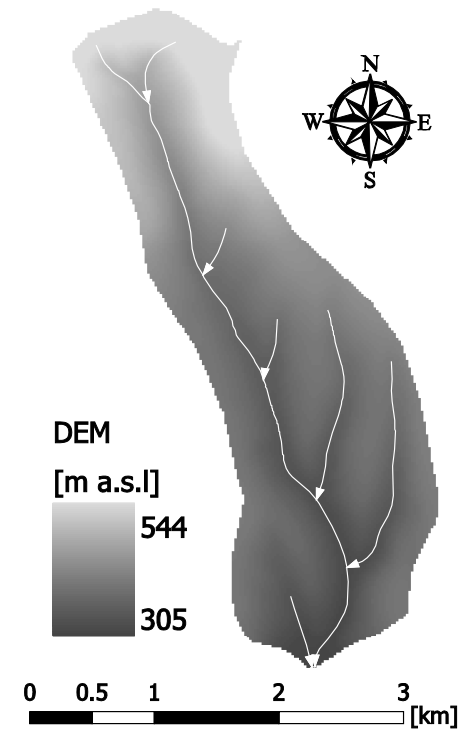

Fig. 2. Digital elevation model of the Svacenický Creek Basin.

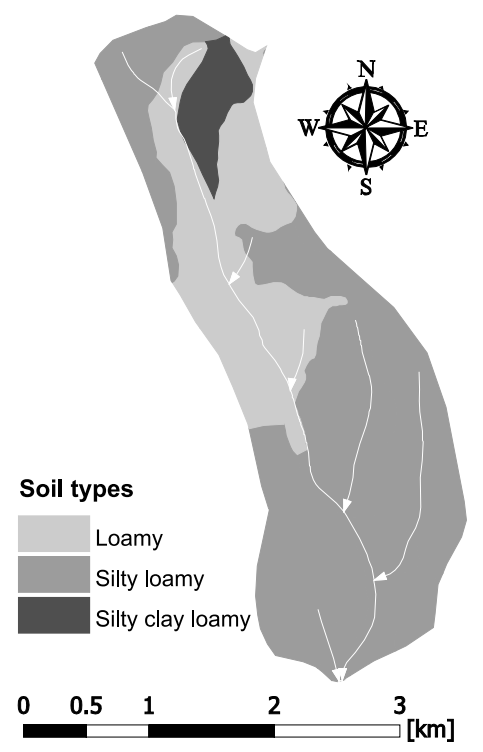

Fig. 3. Soil types in the Svacenický Creek Basin.
The whole basin is covered by a flysh belt created by sand and clay layers. The soils have a character of loamy soils (Fig. 3).

The basin has prevailing agricultural areas, fewer urban areas and bush, but only $4.2 \%$ of the whole catchment area is forested (Fig. 4). In the upper part of the basin there are some small set tlements. Close to its outlet, Svacenický Creek crosses through small urban areas. The climate of the selected catchment is characterised as moderately warm and humid with monthly temperature means from $-5^{\circ} \mathrm{C}$ (January) to $+20^{\circ} \mathrm{C}$ (July).

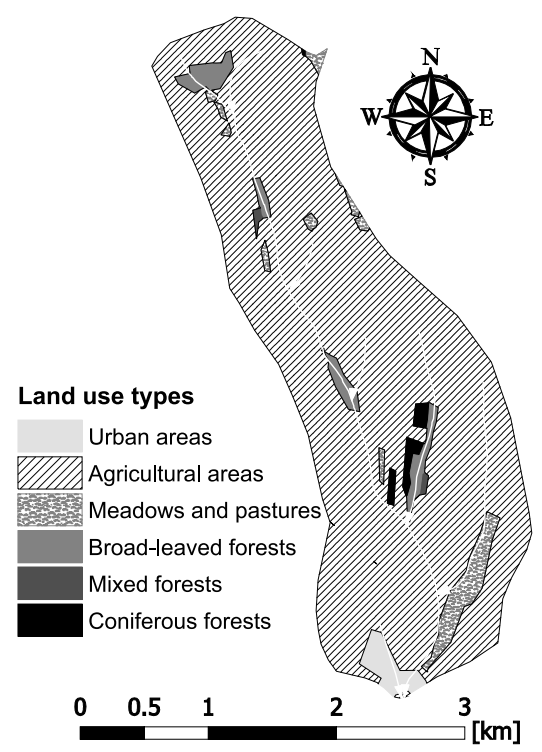

Fig. 4. Land use types in the Svacenický Creek Basin. 
Table 1. Catchment profiles and characteristics of the Svacenický Creek

\begin{tabular}{|l|c|c|c|c|c|}
\hline Profile & $\mathbf{k m}$ & $\begin{array}{c}\mathbf{F} \\
{\left[\mathbf{k m}^{2}\right]}\end{array}$ & $\begin{array}{c}\text { Forested area } \\
{[\%]}\end{array}$ & $\mathbf{x}$ (JTSK) & $\mathbf{y}$ (JTSK) \\
\hline Measured section & 0.77 & 6.15 & 4.2 & -534535 & -1216672 \\
\hline Gauging station & 0.1 & 6.85 & 4.2 & -534734 & -1217191 \\
\hline Outlet & 0.0 & 6.86 & 4.2 & & \\
\hline
\end{tabular}

\section{Description of the meteorological situation}

On the afternoon of 6 June, 2009 the territory of Slovakia was affected by cold front weather and the westerly movement of clouds. A zone of massive storm clouds was passing from the south-west to the area of the White Carpathians. During this situation storms were occurring, which were demonstrated by torrential local rains and hailstorms. At the climatic station in the town of Myjava, torrential rain was recorded. It started at 17:15 UTC and lasted 40 minutes; approximately $60 \mathrm{~mm}$ of precipitation fell during this time. This rainfall's intensity was considered to be a precipitation event with a probability of occurrence of more than 50 years. More precipitation also occurred in the area of the Low Tatras episodes on that day, but neither the intensities nor the total precipitation reached such high values.

\section{Post-flood investigation and evaluation}

Post-flood investigation was done by SHMI Bratislava after the flood (Blaškovičová, 2010). The amount of rainfall was measured at the rain-gauge station in the town of Myjava close to the Svacenický Creek basin. The total measured precipitation on 6 June, 2009 was $61.4 \mathrm{~mm}$, which is quite a high value, especially since this precipitation had fallen between 17:20 and 20:50 UTC, most of it $(59.7 \mathrm{~mm})$ in 40 minutes. The critical factor for the formation of the flash flood was the extreme intensity of the rain. During the post-flood investigation visible markings of the intensive surface runoff were observed as a result of the extremely high intensity of the rain in the Svacenický Creek Basin. What is remarkable is the difference between the 
left and right sides of the lower part of the catchment. While there were significant marks of surface runoff on the right side in the field with maize, the left side had no visible marks of runoff.

The Climatological Department of SHMI constructed a raster map of the daily total precipitation on 6 June, 2009, according to the data from the rain-gauge stations, satellites and radars (Fig. 5).

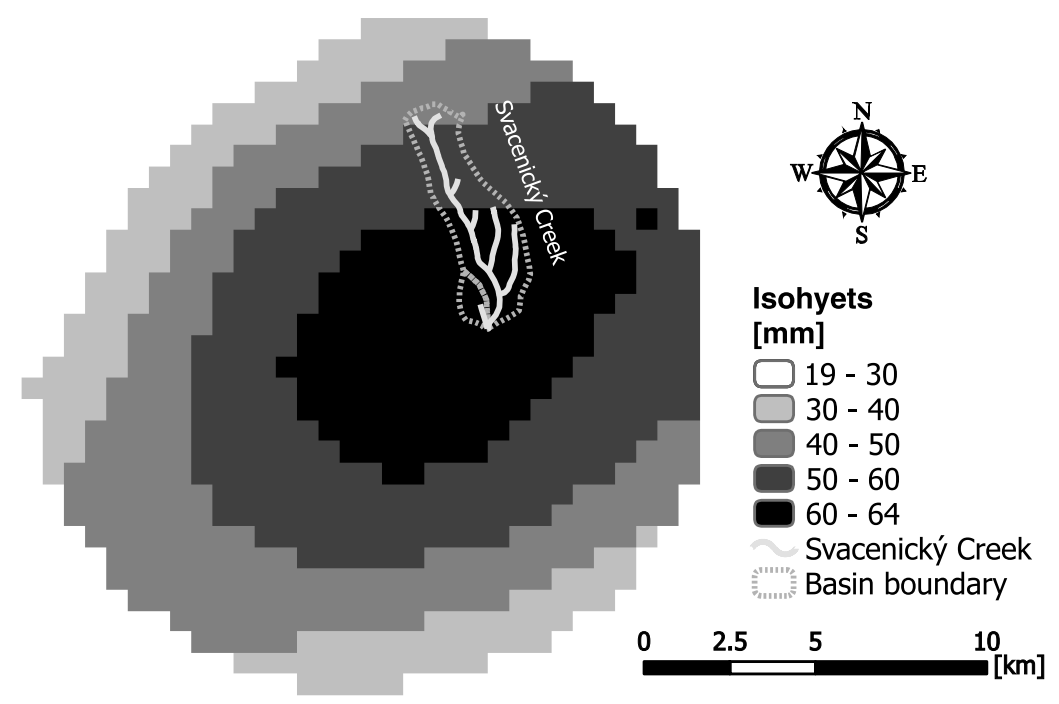

Fig. 5. Daily precipitation totals in the area near the town of Myjava on 6th June, 2009.

The mean value of the total precipitation in the Svacenický Creek Basin was calculated using a GIS interface. The mean daily total precipitation on the catchment to the water-gauging station was $58.97 \mathrm{~mm}$; on the profile measured during the post-event investigation it was $58.21 \mathrm{~mm}$. The volume of the precipitation that fell on the catchment was around $403,940 \mathrm{~m}^{3}$.

Directly on the Svacenický Creek, situated close to the mouth, is a watergauging station established just a few months before the event. The station was not damaged during the flood, so its water-level record was available. This is very important, as it can give reliable information about the timing of the flood. The record shows that before the flood event, the water level was stable. Then it increased slightly (from $7 \mathrm{~cm}$ to $13 \mathrm{~cm}$ ) in a 15-minute interval, but in the next 30 minutes it increased very steeply by more than 
2 meters (to $236 \mathrm{~cm}$ ). The decrease in the water level was also very fast from the peak stage down by two meters in one hour (Fig. 6).

The stream channel at the water-gauging station was filled up and it was partly in backwater from the bridge; therefore, during the post-event investigation an upstream profile (770 $\mathrm{m}$ from the mouth) was selected; there, the peak discharge was estimated. In the selected profile there were quite visible flood marks, so that it was possible to measure the cross profile (Fig. 7).

The flood marks on the left and right bank sites were not at the same

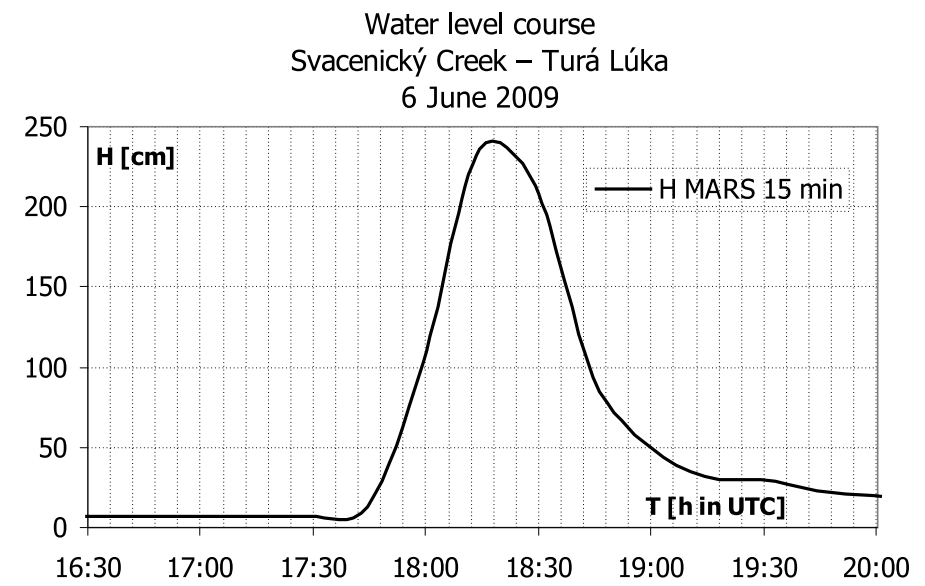

Fig. 6. Water level course of the Svacenický Creek at Turá Lúka water-gauge station in an interval of 15 minutes.

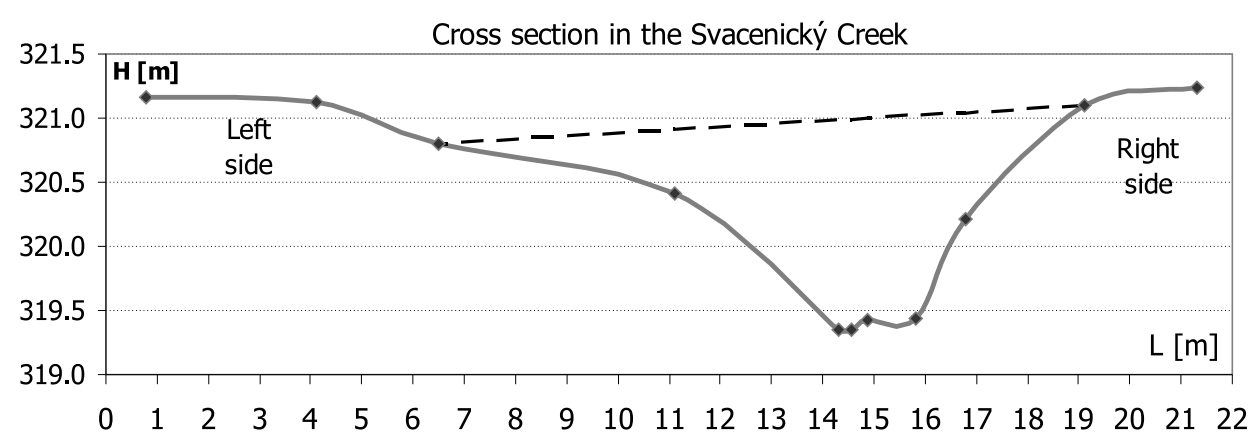

Fig. 7. Cross section at the Svacenický Creek at the $0.77 \mathrm{~km}$. 
level, probably due to the turbulent flow between the trees and bushes. The hydraulic roughness values were taken from a table in the ODOT Hydraulics Manual. The selected values for the channel were from 0.04 to 0.07 ; for the inundation it was 0.04 (minimum), 0.06 (normal), 0.08 (maximum) and alternatively 0.1 (the normal value for "medium-to-dense brush in the summer"). Afterwards, the values of the probable peak discharge $\left(\mathrm{Q}_{1}, \mathrm{Q}_{2}\right.$, $\mathrm{Q}_{3}$ ) for these four hydraulic roughness alternatives and for three longitudinal slope alternatives were calculated (Table 2).

The mean value of the peak discharge in the selected profile can be taken as $15-15.5 \mathrm{~m}^{3} . \mathrm{s}^{-1}$, so in the profile of the water-gauging station, the peak discharge was estimated to be $16.0 \mathrm{~m}^{3} \cdot \mathrm{s}^{-1}$. The specific discharge calculated as the ratio between the peak discharge and the basin area was $2.34 \mathrm{~m}^{3} \cdot \mathrm{s}^{-1} \cdot \mathrm{km}^{-2}$.

The calculated peak flow velocities for the different hydraulic roughness and longitudinal slopes alternatives varied between 1.13 to $2.36 \mathrm{~m} . \mathrm{s}^{-1}$, the average velocity during the peak discharge being $1.71 \mathrm{~m} . \mathrm{s}^{-1}$. The channel velocities were higher than the average cross-profile velocity, including the inundations; they varied from 1.4 to $2.7 \mathrm{~m} . \mathrm{s}^{-1}$.

The volume of the flood was calculated according to the shape of the flood wave (Fig. 6). The duration of the flood wave was defined as between

Table 2. Calculation of the peak discharge (Svacenický Creek)

\begin{tabular}{|c|c|c|c|c|c|c|c|c|}
\hline & $\bar{n}$ & $\mathrm{C}$ & $\begin{array}{c}\mathrm{Q}_{1} \\
{\left[\mathrm{~m}^{3} \cdot \mathrm{s}^{-1}\right]}\end{array}$ & $\begin{array}{c}\mathrm{v}_{1} \\
{\left[\mathrm{~m} \cdot \mathrm{s}^{-1}\right]}\end{array}$ & $\begin{array}{c}\mathrm{Q}_{2} \\
{\left[\mathrm{~m}^{3} \cdot \mathrm{s}^{-1}\right]}\end{array}$ & $\begin{array}{c}\mathrm{v}_{2} \\
{\left[\mathrm{~m} \cdot \mathrm{s}^{-1}\right]}\end{array}$ & $\begin{array}{c}\mathrm{Q}_{3} \\
{\left[\mathrm{~m}^{3} \cdot \mathrm{s}^{-1}\right]}\end{array}$ & $\begin{array}{c}\mathrm{v}_{3} \\
{\left[\mathrm{~m} \cdot \mathrm{s}^{-1}\right]}\end{array}$ \\
\hline \multirow{4}{*}{ 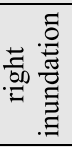 } & 0.04 & 20.3 & 1.0 & 1.1 & 1.1 & 1.2 & 1.2 & 1.2 \\
\hline & 0.06 & 13.6 & 0.7 & 0.7 & 0.7 & 0.8 & 0.8 & 0.8 \\
\hline & 0.08 & 10.2 & 0.5 & 0.5 & 0.6 & 0.6 & 0.6 & 0.6 \\
\hline & 0.10 & 8.1 & 0.4 & 0.4 & 0.4 & 0.5 & 0.5 & 0.5 \\
\hline \multirow{4}{*}{ 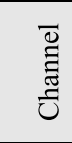 } & 0.04 & 24.7 & 16.6 & 2.4 & 17.8 & 2.5 & 19.1 & 2.7 \\
\hline & 0.05 & 19.8 & 13.3 & 1.9 & 14.3 & 2.0 & 15.3 & 2.2 \\
\hline & 0.06 & 16.5 & 11.1 & 1.6 & 11.9 & 1.7 & 12.8 & 1.8 \\
\hline & 0.07 & 14.1 & 9.5 & 1.4 & 10.2 & 1.5 & 10.9 & 1.6 \\
\hline \multirow{4}{*}{ 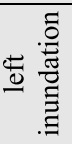 } & 0.04 & 19.4 & 1.0 & 0.9 & 1.1 & 1.0 & 1.2 & 1.0 \\
\hline & 0.06 & 13.0 & 0.7 & 0.6 & 0.7 & 0.7 & 0.8 & 0.7 \\
\hline & 0.08 & 9.7 & 0.5 & 0.5 & 0.6 & 0.5 & 0.6 & 0.5 \\
\hline & 0.10 & 7.8 & 0.4 & 0.4 & 0.4 & 0.4 & 0.5 & 0.4 \\
\hline \multirow{3}{*}{$\begin{array}{l}\frac{0}{0} \\
\frac{0}{3} \\
\frac{0}{3}\end{array}$} & probable & & 14.5 & 1.6 & 15.6 & 1.7 & 16.7 & 1.8 \\
\hline & $\max$ & & 18.6 & 2.1 & 20.0 & 2.2 & 21.5 & 2.4 \\
\hline & $\min$ & & 10.3 & 1.1 & 11.1 & 1.2 & 11.9 & 1.3 \\
\hline
\end{tabular}


17:30 to 21:00 UTC; the total flood wave's duration was estimated to be 210 min (3.5 hour), with the rising limb of the wave being 45 minutes and the decreasing part being $165 \mathrm{~min}$. The total volume of the flood wave (calculated as the sum of the 15-min intervals) was approximately $45,000 \mathrm{~m}^{3}$. This amount represents only $11.1 \%$ of the assumed amount of precipitation that fell on the catchment, which is a relatively low ratio. However, in that area there are mostly loamy soils with good infiltration abilities. No precipitation appeared six days before the event. Previous precipitation occurred on 31th May (recorded precipitation total for 28th May to 31th May was $34 \mathrm{~mm}$ in Myjava station). The previous month, May, was evaluated as normal from a precipitation point of view. The soil moisture therefore was probably not high and allowed the infiltration of a relatively large part of the precipitation. According to some of the witnesses, it is possible that a significant part of the precipitation fell in the form of hailstones. The water volume from the hail could then be melting gradually over several hours, enabling a more intense infiltration of the water.

The mean annual discharges in 2009 and 2010 were both equal to $0.084 \mathrm{~m}^{3} \cdot \mathrm{s}^{-1}$ (happened to be same values, even though the runoff distribution during these years was different). Based on the $\mathrm{N}$-year values actually valid in Slovakia, and according to the methodology for estimating N-year discharges, the assessed peak discharge value equal to $16 \mathrm{~m}^{3} \cdot \mathrm{s}^{-1}$ corresponds to $\mathbf{Q}_{100}$.

\section{Analysis of flood wave by hydrological modelling}

\subsection{Description of the KLEM Model}

As opposed to a post-event estimation, the flash flood event was analysed using the simple KLEM (Kinematic Local Excess Model) rainfall-runoff model (Cazorzi and Dalla Fontana, 1992). This spatially-distributed hydrologic model is based on the availability of raster information of a landscape's topography and soil and vegetation properties. In the model, the SCS-Curve Number (SCS-CN) procedure (U.S. Department of Agriculture, 1986) is applied to a grid for the spatially-distributed representation of runoff-generating processes. A simple method (Da Ros and Borga, 1997; Giannoni et al., 2003) is used to represent the propagation of the runoff for the response of the drainage system. The SCS-CN runoff equation is 
expressed in the form:

$$
\begin{array}{ll}
q=\frac{\left(P-I_{a}\right)^{2}}{\left(P-I_{a}+S\right)} & \text { for } \quad P \geq I_{a} \\
q=0 & \text { for } \quad P<I_{a}
\end{array}
$$

where $q(\mathrm{~mm})$ is the direct runoff's depth; $P(\mathrm{~mm})$ is the rainfall event's depth; $I_{a}(\mathrm{~mm})$ is the initial abstraction or rainfall event required for the initiation of runoff and $S(\mathrm{~mm})$ is a site storage index defined as the maximum possible difference between $P$ and $q$ as $P \rightarrow \infty . P-I_{a}$ is also called "effective rainfall" or $P_{e}$. The SCS-CN method can be applied by specifying a single parameter called the curve number $(\mathrm{CN})$, which is a function of the hydrologic soil-cover complex and ranges from 1 to 100. The spatial distribution of the CN values for this analysis was obtained from previous investigations of the studied area (Cazorzi and Bincoletto, 2005). Following Ponce and Hawkins (1996), the value of $S$ for a given soil is related to the curve number as:

$S=C \cdot\left(\frac{100}{C N}-1\right)$

where $C$ is a calibration parameter [mm] known as "infiltration storativity". The use of the parameter $\mathrm{C}$ allows one to use the spatial distribution of $\mathrm{CN}$ values, which represents the input data in this work, and, at the same time, to simulate the observed flood water balance correctly. In the original SCS-CN equation the value of $C$ is $254 \mathrm{~mm}$, and the initial abstraction is specified as a percentage of $S$. Given the initial exceptionally low soil moisture conditions, the proportionality factor between $I_{a}$ and $S$ (herewith called $X$ ) was considered as a further parameter in this study.

The distributed routing of a runoff is based on the identification of drainage paths and requires the characterization of hillslope and channeled paths. The separation of hillslope elements from channel elements is based on a channelization support area $\left(A_{s}\right)\left[\mathrm{km}^{2}\right]$, which is considered to be constant on a sub-basin scale. Discharge at any location along a river network is represented by:

$Q(t)=\int_{A} q[t-\tau(x), x] \mathrm{d} x$, 
where $A_{s}\left[\mathrm{~km}^{2}\right]$ indicates the area draining to the specified outlet location; $q(t, x)$ is the runoff at time $t$ and location $x$; and $\tau(x)$ is the routing time from $x$ to the outlet of the basin specified by the region $A$. The routing time $\tau(x)$ is defined as

$\tau(x)=\frac{L_{h}(x)}{v_{h}}+\frac{L_{c}(x)}{v_{c}}$

where $L_{h}(x)$ is the distance from the generic point $x$ to the channel network following the steepest descent path; $L_{c}(x)$ is the length of the subsequent drainage path through streams down to the watershed outlet; and $v_{h}$ and $v_{c}\left[\mathrm{~m} . \mathrm{s}^{-1}\right]$ are two invariant hillslope and channel velocities, respectively.

The model also includes a conceptual linear reservoir for base flow modelling, the structure of which is kept invariant over all the basins. The reservoir input is provided by the infiltrated rate, which is computed based on the CN-SCS method; the method is applied on the sub-basin scale.

There are six calibration parameters in the model: the channelization support area $\left(A_{s}\right)$, two kinematic parameters $\left(v_{h}\right.$ and $\left.v_{c}\right)$, the parameter $C$ which is required for the calibration of the SCS-CN procedure, and the parameter $I_{a}$, which is required for the specification of the initial abstraction. The model can even be implemented in very short time steps (10-15 min) and uses a user-defined grid size cell for the description of the landscape's morphology and soil properties.

\subsection{Simulation of the flash flood}

A digital elevation model as well as soil, geology, land use, rainfall and temperature data was required as input data for the model. Afterwards, a map of the $\mathrm{CN}$ values was made (Fig. 8). The total precipitation of the last five days before the flood was lower than $36 \mathrm{~mm}$, so we selected an index of the previous precipitation for zone I.

The velocity in the channels and slopes, the maximum peak, the volume of the flood wave, and the duration of the rising limb, culmination and decline of the flood wave during the flood were determined from the results of the detailed post-event analyses and field survey several weeks after the events and from personal interviews. These estimated values were compared with the results from the KLEM model. At first, the routing parameters 


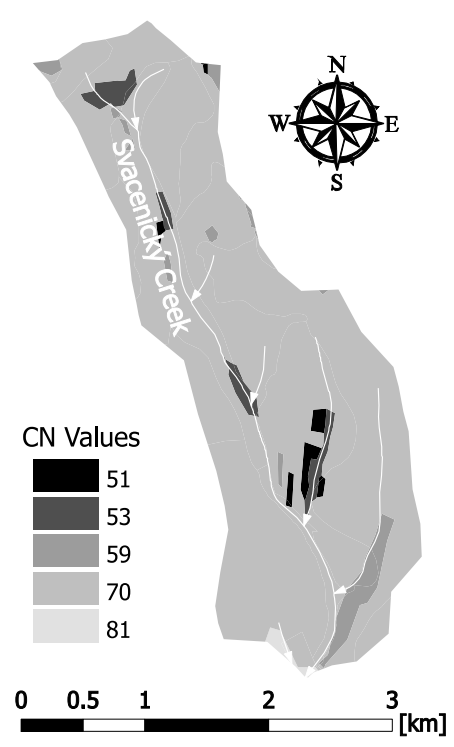

Fig. 8. CN values in the Svacenický Creek Basin.

have to be set. Their lower threshold is the interface between a channel and no channel cells. The channel cells reach the channel flow's velocity; no channel cells are controlled by the slope's velocity. The KLEM parameters consist of parameter $\mathrm{X}$, which regulates the infiltration's storativity; the recession parameter influences the quantity of the base flow, and the initial abstractions have an impact on the initial rainfall losses (Table 3). The simulated discharge (Qtot) is composed of the base flow and direct runoff (Fig. 9).

The simulated characteristics of the flash flood event are listed in Table 4.

Table 3. Best values of the KLEM parameters during simulation

\begin{tabular}{|c|c|c|c|c|c|}
\hline \multicolumn{3}{|c|}{ Routing } & \multicolumn{3}{|c|}{ KLEM } \\
\hline 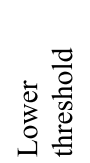 & 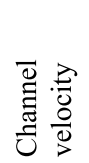 & 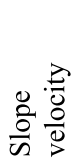 & 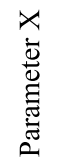 & 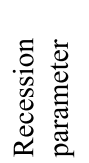 & 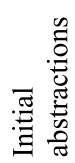 \\
\hline 5 & 4.0 & 0.1 & 7.2 & 4.0 & 0.0 \\
\hline
\end{tabular}




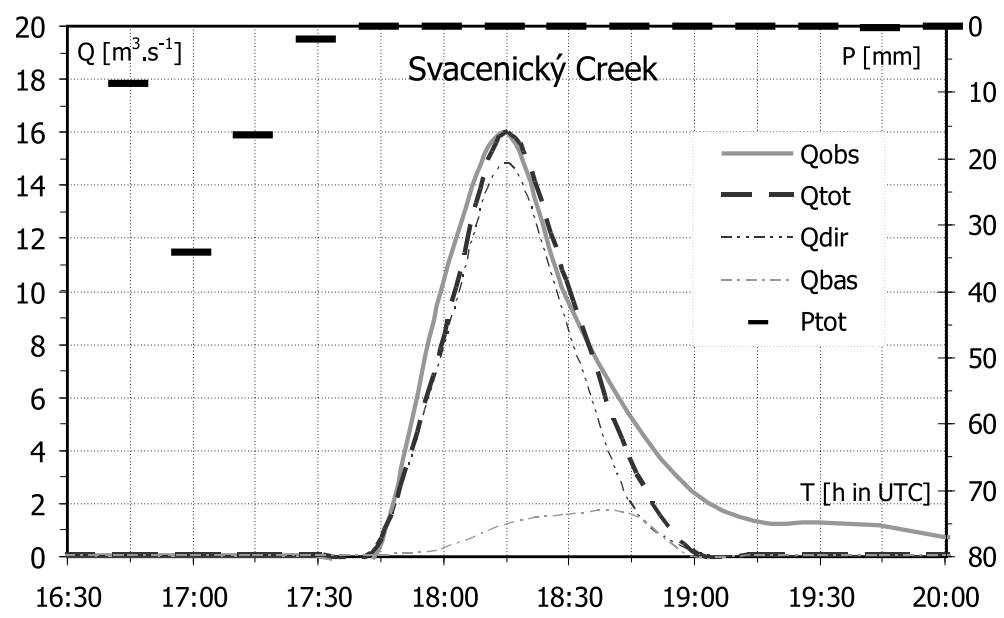

Fig. 9. Simulation of the flood wave's cross section at Svacenický Creek at $0.77 \mathrm{~km}$ by the KLEM model.

Table 4. Rainfall-runoff characteristics in each section simulated by the KLEM model

\begin{tabular}{|c|c|c|c|c|c|c|c|c|c|}
\hline Section & 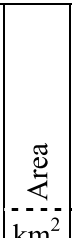 & 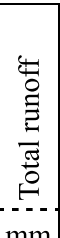 & 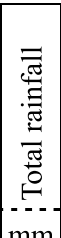 & 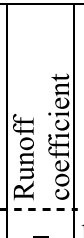 & 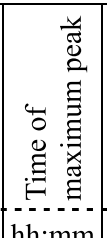 & 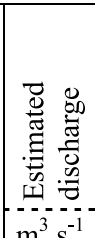 & 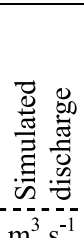 & 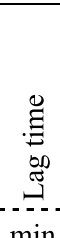 & 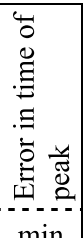 \\
\hline Svacenický Creek & 6.99 & 5 & 61 & 0.08 & 19:15 & 16 & 16 & 0 & 0 \\
\hline
\end{tabular}

The estimated maximum peak discharges from the post-event analyses are compared with the simulated maximum peaks. The results proved a very good consistency of the simulated and estimated discharges. There was not any lag time or error at the time of the peak.

\section{Conclusion and discussion}

In the modelling of flash flood events using the KLEM hydrological model the greatest difficulties have mainly followed from uncertainties in the rain- 
fall data input. The surrounding precipitation stations did not catch the local rainfall events sufficiently.

Generally, from the outcome illustrated in Fig. 9, it can be seen that the KLEM distributed rainfall-runoff model was able to reproduce the selected storm event responses sufficiently. The consistency of the estimated and simulated values by the KLEM model was evident both in time and space. A relatively good correspondence between the simulated and estimated discharges in the Svacenický Creek Basin was achieved. The simulated flood's wave volume is slightly underestimated against the estimated one. There was not any lag time or error at the time of the peak, but we simulated only one flood wave in one cross section.

The main focus of the hydrological simulation of flash flood responses is the best achievement of the maximum peak and behaviour of a flood wave. The crucial problem of estimating the occurrence and magnitude of flash floods is the lack of measured data, particularly in small ungauged catchments. In many cases, even if radar measurements of the precipitation are not available, there is a problem estimating not only the sum of a rainfall event, but also the rainfall's distribution over time and in space. In this case all the data and information obtained from the post-event analyses are useful. If other data showing the topography, soil and land use characteristics are available, spatially distributed rainfall-runoff hydrological models with a high spatial resolution of a basin's physiographical and morphological characteristics can represent a good tool for sufficiently reproducing an analysis of a storm event's response and can decrease the uncertainties of estimating flash floods.

Differences in the flood response of basins of varying catchment sizes are related to the effect of the spatial organization of the banded convection, the contrasting fractional coverage of the rainfall following from the basin's size and structure, and the differential response due to the highly nonlinear relationship between rainfall and runoff (Borga et al., 2007). An important source of nonlinearity is related to the strong dependency of the basin's response time to the storm's accumulation.

The degree of nonlinearity arising from the available data could not be reproduced by a flood response model with an invariant parameterization (Borga et al., 2007). Post-flood surveys and interviews play an important role as an information source. Together with the estimations of the maxi- 
mum peak and total rainfall in space and over time as well as the readily available GIS data, hydrologic modelling allowed us to generate a much more complete picture of the storm and flood environments than would otherwise be available at ungauged basins.

Acknowledgments. This work was supported by the Slovak Research and Development Agency under Contract No. LPP-0254-07 and APVV-0496-10 and the VEGA Grant Agency No. 1/0103/10.

\section{References}

Anquetin S., Yates E., Ducrocq V., Samouillan S., Chancibault K., Gozzini B., Pasi F., Pasqui M., Garcia M., Martorell M., Romero R., Silvio D., Accadia C., Casaidi M., Mariani S., Ficca G., Chesa P., 2005: The 8 and 9 september 2002 flash-flood event in France: an intercomparison of operational and research meteorological models. Nat. Hazard. Earth Systems, 5, 741-754.

Blaškovičová L., 2010: Evaluation Methods of Flash Floods. Phd. Thesis, Slovak University of Technology in Bratislava, Faculty of Civil Engineering, Department of Land and Water Resources Management, Bratislava, Slovakia, 164 p.

Blöschl G., Reszler C., Komma J., 2008: A spatially distributed flash flood forecasting model. Environmental Modelling \& Software 23, 4, 464-478.

Borga M., Boscolo P., Zanon F., Sangati M., 2007: Hydrometeorological Analysis of the 29 August 2003 Flash Flood in the Eastern Italian Alps. Journal of Hydrometeorology, 8, 1049-1067.

Carpenter T. M., Sperfslagea J. A., Georgakakosa K. P., Sweeneyc T., Freadc D. L., 1999: National threshold runoff estimation utilizing GIS in support of operational flash flood warning systems. Journal of Hydrology, 224, 21-44.

Cazorzi F., Dalla Fontana G., 1992: L'utilizzo dei sistemi informativi geografici nello studio idrologico di bacino. Quaderni di Idronomia Montana, 12, 83-115 (in Italian).

Cazorzi F., Bincoletto L., 2005: Modellazione dei processi idrologici. La prevenzione del rischio idrogeologico nei piccoli bacini montani dellaregione: Esperienze e conoscenze acquisite con il progetto CATCHRISK. Convegno finale del Progetto CATCHRISK, Udine, Italy, INTERREG IIIB, 45-74 (in Italian).

Da Ros D., Borga M., 1997: Use of digital elevation model data for the derivation of the geomorphologic instantaneous unit hydrograph. Hydrol. Processes, 11, 13-33.

Delrieu G., Ducrocq V., Gaume E., Nicol J., Payrastre O., Yates E., Kirstetter P. E., Andrieu H., Ayral P. A., Bouvier C., Creutin J. D., Livet M., Anquetin A., Lang M., Neppel L., Obled C., Parent-du-Chatelet J., Saulnier G. M., Walpersdorf A., Wobrock W., 2005: The catastrophic flash-flood event of 8-9 September 2002 in the Gard region, France: a first case study for the Ce'vennes-Vivarais Mediterranean Hydrometeorological Observatory. Journal of Hydrometeorology, 6, 34-52. 
Gaume E., Livet M., Desbordes M., Villeneuve J. P., 2004: Hydrologic analysis of the Aude, France, flash flood 12 and 13 November 1999. Journal of Hydrology, 286, $135-154$.

Gaume E., Bain V., Bernardara P., Newinger O., Barbuc M., Bateman A., Blaškovičová L., Blöschl G., Borga M., Dumitrescu A., Daliakopoulos I., Garcia J., Irimescu A., Kohnová S., Koutroulis A., Marchi L., Matreata S., Medina V., Preciso E., Sempere-Torres D., Stancalie G., Szolgay J., Tsanis I., Velasco D., Viglione A., 2009: A collation of data on European flash floods. Journal of Hydrology, 367, $70-78$.

Georgakakos K. P., 2006: Analytical results for operational flash flood guidance. Journal of Hydrology, 317, 1-2, 81-103.

Giannoni F., Smith J. A., Zhang Y., Roth G., 2003: Hydrologic modeling of extreme floods using radar rainfall estimates. Adv. Water Resources, 26, 195-200.

Norbiato D., Borga M., Sangati M., Zanon F., 2003: Regional frequency analysis of extreme precipitation in the eastern Italian Alps and the August 29, 2003 flash flood. Journal of Hydrology, 345, 149-166.

Norbiato D., Borga M., Esposti S. D., Gaume E., Anquetin S., 2008: Flash flood warning based on rainfall thresholds and soil moisture conditions: An assessment for gauged and ungauged basins. Journal of Hydrology, 362, 274-290.

ODOT Hydraulics Manual.

Ponce V. M., Hawkins E. R. H., 1996: Runoff curve number: Has it reached maturity? J. Hydrol. Eng., 1, 11-19.

Reed S., Schaake J., Zhang Z., 2007: A distributed hydrologic model and threshold frequency-based method for flash flood forecasting at ungauged locations. Journal of Hydrology, 337, 402-420.

U.S. Department of Agriculture, 1986: Urban hydrology for small watersheds. U.S. Department of Agriculture Tech. Release, 55, $164 \mathrm{p}$.

Younis J., Anquetin S., Thielen J., 2008: The benefit of high resolution operational weather forecasts for flash-flood warning. Hydrology and Earth System Sciences and Discussion, 5, 345-377. 